\title{
Zasady leczenia niezłośliwych guzów krtani u chorych w wieku podeszłym - amyloidoza krtani
}

\author{
Ways of treatment of non-malignant laryngeal tumors \\ in older patients - amyloidosis laryngeal
}

\author{
Agnieszka Morawska, Maciej Wiatr, Jacek Składzień
}

Katedra i Klinika Otolaryngologii Collegium Medicum Uniwersytetu Jagiellońskiego w Krakowie Kierownik: prof. dr hab. med. J. Składzień

\begin{abstract}
Summary
Introduction. Amyloidosis' are the heterogeneous group of diseases characterized by extracellular accumulation of secondary protein structures causing progressive disturbances of the organs. Amyloid deposits are localized mainly in the tissues of parenchymal origin (spleen, kidneys, liver) and as far as otorhinolaryngologic organs are concerned the primary pathological process is rare. Aim. The case presentation and the diagnostic and surgical procedure analysis with the assessment of the effects of therapy in patients in elderly age with amyloidosis of larynx. Material and methods. A 82-year-old patient with a tumor of the larynx hospitalized in Otorhinolaryngology Clinic in Cracow. The first symptom of the pathologic process in this patient was an increasing laryngeal dyspnoe and the preliminary macroscopic assessment based on indirect laryngoscopy and endoscopy suggested the proliferative process from the group of non-epithelial neoplasm. Results. In this case tracheotomy was performed and four days later the pathologic change was endoscopically removed from larynx. The improvement of the local state was achieved which enabled to decannulate the patient. Conclusions. The amyloid deposits in otorhinolaryngologic organs are rare. Isolated changes in larynx suggesting malign neoplasm are the benign changes but on account of the specificity of the organ they can be a real threat to life.
\end{abstract}

Hasła indeksowe: amyloidoza, wiek senioralny

Ke y words: amyloidosis, older patients

Otolaryngol Pol 2008; LXII (2): 141-144 @ 2008 by Polskie Towarzystwo Otorynolaryngologów - Chirurgów Głowy i Szyi

\section{WSTĘP}

Amyloidozy są grupą chorób charakteryzujących się zewnątrzkomórkowym gromadzeniem drugorzędowych struktur białkowych (amyloidu), prowadzącym do postępującego zaburzenia funkcji narządów [1, 2]. Gromadzący się amyloid może składać się z kilku rodzajów włókien. Każde z włókien zbudowane jest w 90\% z dominującego, charakterystycznego składnika, przeplatanego wieloma komponentami o nieustalonym znaczeniu: osoczowym białkiem P(SAP), składowymi dopełniacza, apolipoproteiną E (apoE) oraz siarczanami heparanów (HSPG) [3, 4].

Historyczna klasyfikacja amyloidoz wyróżnia postać miejscową i uogólnioną. Aktualny podział opierający się na budowie biochemicznej przedstawiono w tabeli I

Niezwykła różnorodność narządowego występowania złogów amyloidu pozostaje jednym z najważniejszych i wciąż nierozwiązanych problemów w badaniach nad tą chorobą. Swoiste białka agregują głównie w określonych narządach docelowych: $\beta$ 2 mikroglobulina w stawach, łańcuch fibrynogenu A w nerkach. Natomiast w amyloidzie AL złogi zajmować mogą praktycznie każdy narząd $[5,6]$.

Odosobniona amyloidoza krtani występuje bardzo rzadko i stanowi mniej niż 1\% wśród wszystkich guzów łagodnych tego narządu [7-9]. Pierwszy przypadek skrobiawicy w tej lokalizacji opisany został w 1875 roku przez Burowa. Do 1990 roku w literaturze światowej opisano około 300 przypadków tej choroby w obrębie górnych dróg oddechowych.

Do dnia dzisiejszego nie udało się ustalić etiologii i dokładnej patogenezy procesu odkładania amyloidu w krtani. Nie udowodniono związku tej choroby z paleniem tytoniu, piciem alkoholu czy nawracającymi infekcjami.

Amyloidoza krtani dotyczy częściej mężczyzn (3:1) w 4-6 dekadzie życia. Proces chorobowy najczęściej

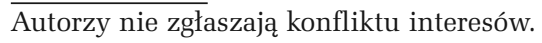


Tabela I. Podziat amyloidoz $(20,21)$

\begin{tabular}{|c|c|c|}
\hline Typ amyloidozy & Białko w narządzie docelowym & Choroba \\
\hline Układowy & $\begin{array}{l}\text { łańcuchy lekkie Ig (Al) } \\
\text { ranstyreina } \\
\text { AA } \\
\beta 2 \text {-mikroglobulina } \\
\text { łańcuchy ciężkie lg }\end{array}$ & $\begin{array}{l}\text { gammapatie } \\
\text { rodzinna amyloidoza } \\
\text { amyloidoza związana z zapaleniem } \\
\text { amyloidoza związana z dializą } \\
\text { amyloidoza układowa }\end{array}$ \\
\hline Dziedziczny & $\begin{array}{l}\text { łańcuchy } \alpha \text { fibrynogenu } \\
\text { apolipoproteina } A \\
\text { lizozym }\end{array}$ & $\begin{array}{l}\text { rodzinna amyloidoza układowa } \\
\text { rodzinna amyloidoza układowa } \\
\text { rodzinna amyloidoza układowa }\end{array}$ \\
\hline Ośrodkowy & $\begin{array}{l}\text { prekursory białka } \beta \\
\text { białko prionowe } \\
\text { nystatyna } \mathrm{C}\end{array}$ & $\begin{array}{l}\text { choroba Alzheimera } \\
\text { choroba C-J } \\
\text { dziedziczne krwotoki mózgowe }\end{array}$ \\
\hline Oczny & $\begin{array}{l}\text { gelsolina } \\
\text { laktoferryna } \\
\text { keratoepitelina }\end{array}$ & $\begin{array}{l}\text { rodzinna amyloidoza } \\
\text { rodzinna amyloidoza rogówki } \\
\text { rodzinna dystrofia rogówki }\end{array}$ \\
\hline Zlokalizowany & $\begin{array}{l}\text { kalcytonina } \\
\text { amelina } \\
\text { prolaktyna } \\
\text { keratyna } \\
\text { medyna }\end{array}$ & $\begin{array}{l}\text { rak rdzeniasty tarczycy } \\
\text { insulinoma } \\
\text { amyloidoza przysadkowa } \\
\text { amyloidoza skórna } \\
\text { amyloidoza aortalna }\end{array}$ \\
\hline
\end{tabular}

obejmuje fałdy głosowe, kieszonki krtaniowe, spoidło przednie. Złogi białkowe mogą się lokalizować $\mathrm{w}$ drogach oddechowych w przestrzeniach podnabłonkowych w formie rozproszonej (diffuse type) lub przyjmować ograniczoną formę guza (nodular type).

Początkowo objawy amyloidozy krtani są bardzo dyskretne, z czasem mogą pojawić się chrypka, kaszel, zaburzenia połykania. Bardzo rzadko występuje duszność [10-12].

Do ostatecznej weryfikacji i potwierdzenia rozpoznania służy biopsja narządu i ocena histopatologiczna.

\section{CEL}

Prezentacja przypadku z analizą postępowania diagnostycznego i chirurgicznego oraz oceną efektów leczenia u pacjenta ze skrobiawicą krtani w wieku senioralnym.

\section{OPIS PRZYPADKU}

Mężczyzna, lat 83, przyjęty do Kliniki w trybie planowym celem badania endoskopowego krtani i gardła dolnego. Chory skarżył się na trwającą od 15 lat chrypkę, początkowo okresową, a od roku stałą. Dodatkowo od 3 miesięcy pojawiła się okresowa duszność, głównie w trakcie wysiłku. Pacjent konsultowany w Rejonowej Poradni Laryngologicznej
(Dgn. Tu laryngis. Raucedo), nie wyrażał wielokrotnie zgody na proponowaną diagnostykę endoskopową i ew. leczenie operacyjne.

W wywiadzie chory leczony od 15 lat z powodu nadciśnienia tętniczego oraz żylaków kończyn dolnych. Nie operowany. Nie palił papierosów, alkohol spożywał wyłącznie okazjonalnie.

W badaniu przedmiotowym: CTK 150/80 mm Hg, ASM - 70/min. Nad polami płucnymi szmer pęcherzykowy, bez cech zastoju. Brzuch miękki, niebolesny, bez oporów patologicznych. Chory zorientowany w czasie, miejscu i przestrzeni.

W wynikach badań biochemicznych nie stwierdzono odchyleń od normy.

W badaniu pośrednim krtani stwierdzono podśluzówkowy, gładki guz lewego fałdu nalewkowonagłośniowego oraz lewej nalewki, ograniczający ruchomość lewego fałdu głosowego i nagłośni. Guz przysłaniał w 1/3 tylnej szparę głośni. Prawa połowa krtani w widocznym obszarze była bez zmian patologicznych.

Chory zakwalifikowany został do tracheotomii oraz endoskopowej oceny krtani w znieczuleniu ogólnym.

W sposób typowy wykonano tracheotomię na poziomie III pierścienia tchawicy. Założono rurkę tracheotomijną nr 8,5. Następnie przy wykorzystaniu zestawu Kleinsassera wykonano directoskopowe badanie krtani. Stwierdzono kulisty, gładki guz spoidła tylnego, lewej nalewki, z którego pobrano wycinki do badania histopatologicznego. 
Rozpoznanie hist-pat: Amyloidoza AL. Ogniskowo pomiędzy masami amyloidu widoczne nagromadzenie plazmocytów wykazujących ekspresję łańcuchów lekkich lambda.

W kolejnym etapie chory zakwalifikowany został do operacji usunięcia guza z krtani w znieczuleniu ogólnym. Endoskopowo we fragmentach usunięto duży guz spoidła tylnego, lewej nalewki. Założono sondę do przełyku przez nos. Sondę do karmienia utrzymano przez 4 kolejne dni po zabiegu operacyjnym. W 7 dobie po zabiegu, usunięto rurkę tracheotomijną. Pacjent pozostaje w pooperacyjnej okresowej kontroli laryngologicznej. Jak dotąd nie stwierdzono nawrotu choroby.

\section{WYNIKI}

Wywiad (płeć, brak obciążenia rodzinnego), prawidłowe wyniki badań dodatkowych przemawiają w opisywanym przypadku za izolowaną postacią amyloidozy w krtani. Podstawą rozpoznania był wynik badania patomorfologicznego bioptatu pobranego z guza krtani. Przeprowadzone odczyny immunohistochemiczne wykazały dodatnią reakcję przeciw komponentowi P oraz z przeciwciałem przeciw łańcuchom lekkim immunoglobulin, co potwierdziło rozpoznanie typu amyloidozy - AL.

\section{DYSKUSJA}

Amyloidoza (skrobiawica) jest wspólnym mianownikiem dla grupy chorób prowadzących do pozakomórkowego odkładania się w tkankach i narządach patologicznej substancji białkowej zwanej amyloidem. Narządy otolaryngologiczne rzadko są miejscem lokalizacji tej choroby. Izolowane, łagodne zmiany w krtani mogą sugerować ze względu na swój obraz makroskopowy nowotwory o charakterze złośliwym głównie z grupy nowotworów nienabłonkowych (mięsaków). Proces chorobowy dotyczy w większości przypadków mężczyzn w przedziale wiekowym 40-60 lat, a dominującym objawem jest chrypka, rzadko kaszel czy zaburzenia połykania, wyjątkowo opisywane są przypadki nasilonej duszności [13-17].

Opisywane były pojedyncze przypadki amyloidozy w krtani w wieku dziecięcym [13, 18].

Zaawansowany wiek chorego opisanego w naszej pracy wynika najprawdopodobniej z późnego rozpoznania, z powodu braku zgody pacjenta na wykonanie diagnostyki.
Przedstawiony przypadek stanowi postać amyloidozy typu AL (postać ograniczona), która jest najczęstszym typem skrobiawicy narządowej. Zmiany ograniczone, podobne jak w przedstawianym przypadku, rokują zdecydowanie lepiej w porównaniu ze zmianami obserwowanymi w postaci rozlanej. Postępowaniem z wyboru w postaci ograniczonej jest leczenie chirurgiczne, które może być uzupełnione leczeniem zachowawczym, mającym na celu zmniejszenie lub eliminację komórek plazmatycznych produkujących białko amyloidu.

W dostępnym piśmiennictwie zwraca uwagę, iż zmiany w obrębie krtani czy zatok obocznych nosa mogą być pierwszym sygnałem rozwoju amyloidozy oskrzelowo-płucnej. Postać ta obejmuje wyłącznie układ oddechowy i dotyczy najczęściej osób w szóstej i siódmej dekadzie życia. Dlatego chorzy po zabiegu powinni być poddawani okresowym badaniom nie tylko laryngologicznym, ale również pulmonologicznym [19-21].

\section{WNIOSKI}

1. Złogi amyloidu w obrębie narządów otolaryngologicznych występują rzadko.

2. Izolowane zmiany w krtani sugerujące nowotwór złośliwy są zmianami łagodnymi, ale ze względu na specyficzność narządu mogą stanowić zagrożenie dla życia.

3. Leczeniem z wyboru jest postępowanie chirurgiczne oraz okresowa pooperacyjna kontrola.

4. Zaawansowany wiek chorych wymusza w każdym przypadku indywidualne podejście diagnostyczne i lecznicze.

\section{PIŚMIENNICTWO}

1. Kenedy TL, Patel NM. Surgical management of localized amyloidosis. Laryngoscope 2000;110: 918-923.

2. Berg AM, Troxel RF, Gril lone G, i wsp., Localized amyloidosis of the larynx: evidence for light chain composition. Ann Otol Rhinol Laryngol 1993; 2: 884-889.

3. Nagasaka T, Lai R, Kuno K, Nakashima N. Localized amyloidosis and extramedullary plasocytoma involving the larynx of child. Hum Pathol 2001; 32: 132-134.

4. McAlpine JC, Fuller AP. Localized laryngeal amyloidosis: A report of case with a review of the literature. Laryngol Otol 1964; 78: 296-314.

5. Michaels L, Hyams VJ. Amyloid in localized deposits and plasmacytomas of the respiratory tract. J Pathol 1979; 128: 29-38. 
6. Simpson GT II, Strong MS, Skinner M, Cohen AS. Localized amyloidosis of the head and nack and upper aerodigestive and lower respiratory tract. Ann Otol Rhinol Laryngol 1984; 93: $374-379$

7. Mitrani M, Biller HF. Laryngeal amyloidosis. Laryngoscope 1985; 95: 1346-1347.

8. New GB. Amyloid tumors of the upper air passages. Laryngoscope 1919; 29: 327-341.

9. Cunnane G. Amyloid proteins in pathogenesis of AA amyloidosios. Lancet 2001; 358: 24-25.

10. Buxbaum J. The amyloidoses. Rheumatol 1998; 27: 1-10.

11. Heiner ER. Primary amyloidosis of the larynx. Ann Otol Rhinol Laryngol 1968; 87: 413-415.

12. Holinger PH, Jonston KC, Delgado A. Amyloid tumors of the larynx et trachea. Arch Otolaryngol 1959; 70: 555-561.

13. Hurbis CG, Holinger LD. Laryngealamyloidosis in a child. Ann Otol Rhinol Laryngol 1990; 99: 105-107.

14. Mcllwain JC, Shepperd HW. Laser treatment of primary amyloidosis of the larynx. J Laryngol Otol 1986; 100: 1079-1080.

15. Ferrara G, Boscaino A. Nodular amyloidosis of hr larynx. Pathologica 1995; 87: 94-96.

16. Watanabe H, Makishima K, Komiyama S, Hiroto I. Surgical treatment of the laryngotracheal amyloidosis. Auris Nasus Larynx 1984; 11: 157-162.
17. Bennett JD, Chowdhury CR. Primary amyloidosis of the larynx. J Laryngol Otol 1994; 108: 339-340.

18. Linke RP. Therapy of amyloid diseases. Ren Fail 1993; 15: 395-400.

19. Takeda Y, Sekiyama S, Suzuki A, Hirose H. Localized oral amyloidosis: Ultrastructural and immunohistochemical study. J Oral Pathol 1987; 16: 278-281.

20. Cohen AS, Connors LH. The pathogenesis and biochemistry of amyloidosis. J Pathol 1987; 151: 1-10.

21. Prochorec-Sobieszek M, Bilińska Z, Wagner T. Amyloidoza serca. Współcz Pogl Kardiol Pol 2004; 61: 63-66.

\author{
Adres autora: \\ Agnieszka Morawska \\ ul. Śniadeckich 2 \\ 31-531 Kraków
}

Pracę nadesłano: 22.08.2007 r 